\title{
脂環式ジイソシアナートー銅アセチルアセトナート錯体 触媒によるメタクリル酸メチルの重合
}

\author{
井上眞一*1·前田裕二*1 · 永井 康晴*1 $\cdot$ 岡本 弘*1
}

（受付 2001 年 11 月 8 日・審査終了 2002 年 1 月 28 日）

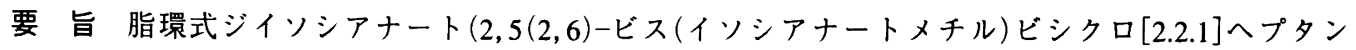
(NBDI)，1,3-ビス(イソシアナートメチル)シクロヘキサン（H6XI）および3-イソシアナートメチル-3, 5,5-トリメチルシクロヘキシルイソシアナート(IPDI)）と銅(II) アセチルアセトナートとからなる錯体 を合成し,メタクリル酸メチルの重合反応を検討した. 重合活性は比較的高く, 分子量分布の狭い $\left(M_{\mathrm{w}}\right)$ $\left.M_{\mathrm{n}}<1.4\right)$ 高分子量 $\left(M_{\mathrm{n}}>70 \times 10^{4}\right)$ のポリマーが得られた. とりわけ，3ーイソシアナートメチル-3,5,5トリメチルシクロヘキシルイソシアナートー銅アセチルアセトナート錯体(IPDI-Cu (acac) 2 )を用いた場合, 分子量は $M_{\mathrm{n}}=97.1 \times 10^{4}$ と高分子量であり, 分子量分布は $M_{\mathrm{w}} / M_{\mathrm{n}}=1.26$ と非常に狭いポリマーが得られた. また, 速度論的検討から, 重合の速度式は $R_{\mathrm{p}}=k[\mathrm{MMA}]^{2.3}$ [IPDI-Cu (acac) $\left.{ }_{2}\right]^{0.44}$ と求まった. IPDI-Cu (acac $)_{2}$ 錯体が生成ポリマーの立体規則性に影響を与えることが明らかとなり，比較的アイソタクト連鎖に富むも のが得られた。
\end{abstract}

\section{1 緒言}

メタクリル酸メチル（MMA）はラジカル重合, イオ ン重合などさまざまな機構で重合が可能であるため, 新 しい重合触媒の開発には非常に興味深い単量体の 1 つで ある。重合触媒としてはメタロセン触媒系が主に用いら れてきたがリーフ, 最近新しい触媒系として, 後周期遷移 金属錯体触媒に注目が集まっている。なかでも，金属ア セチルアセトナート系触媒に関して盛んに研究が行われ ている ${ }^{8)-10)}$. 重合反応において触媒の選択は重要な位置 を占め, 生成ポリマーの立体・幾何構造特異性の発現お よび分子量 $\left(M_{\mathrm{n}}\right)$ あるいは分子量分布 $\left(M_{\mathrm{w}} / M_{\mathrm{n}}\right)$ の制御 に大きくかかわっている.

筆者らは, 新しい触媒系としてジイソシアナート一金 属アセチルアセトナート錯体を合成し，それを触媒とし た MMAの重合を検討し, 脂肪族ジイソシアナートであ るへキサメチレンジイソシアナートとコバルト(II)，二 ッケル (II) および銅 (II) アセチルアセトナートとから なる錯体が，比較的温和な条件下での重合触媒として機 能することを明らかとしている"”。また，コバルトある いは銅錯体が $M_{\mathrm{n}}$ および $M_{\mathrm{w}} / M_{\mathrm{n}}$ に大きな影響を与え， $M_{\mathrm{w}} / M_{\mathrm{n}}$ の狭い高分子量体を得るためのよい触媒となり うることも明らかとしている。

\footnotetext{
*1 愛知工業大学工学部応用化学科（《470-0392 豊田市八草町 八千草 1247)
}

そこで, 本研究では配位子としては比較的立体的にか さ高い, 脂環式ジイソシアナートである，2,5(2,6)-ビ ス(イソシアナートメチル)ビシクロ[2.2.1]へプタン (NBDI)，1,3-ビス(イソシアナートメチル)シクロヘキ サン（HoXI）および3ーイソシアナートメチル-3, 5, 5トリメチルシクロヘキシルイソシアナート（IPDI）を配 位子とした銅アセチルアセトナート錯体を合成し，それ ら錯体を触媒として用い，MMAの重合反応に及ほす影 響について検討し，その結果について報告する。

\section{2 実験}

\section{1 試薬}

メタクリル酸メチル (MMA), メタクリル酸エチル （EMA）およびメタクリル酸 $n$ ーブチル（BMA）はナカ ライテスク (株) 製の規格第 1 級試薬を水素化カルシウム $\left(\mathrm{CaH}_{2}\right)$ 上で減圧蒸留することにより精製したものを使 用した。銅 (II) アセチルアセトナート $\left(\mathrm{Cu}(\mathrm{acac})_{2}\right)$ は ナカライテスク (株) 製の規格第 1 級試薬を市販品のまま 使用した. 2,5(2,6)-ビス(イソシアナートメチル)ビシ クロ[2.2.1]へプタン (NBDI) は三井化学(株)提供品を, 1,3-ビス(イソシアナートメチル)シクロヘキサン（H XDI）は武田薬品工業(株) 製を，3ーイソシアナートメチ ル-3, 5, 5-トリメチルシクロヘキシルイソシアナート （IPDI）はヒュルスジャパン(株)製の試薬をアルゴン雲 囲気で減圧蒸留により精製したものを使用した。塩化メ チレン, アセトンおよびテトラヒドロフラン（THF）は 
ナカライテスク(株)製の規格特級試薬を常法により精製 したのちに使用した。

\section{2 触媒の調製}

$\mathrm{Cu}(\mathrm{acac})_{2}(0.50 \mathrm{~g}, 1.91 \mathrm{mmol})$ と IPDI $(0.43 \mathrm{~g}, 1.93$ $\mathrm{mmol})$ とをアルゴン䨌囲気で塩化メチレン $(25 \mathrm{~mL})$ 中, 室温 $\left(23^{\circ} \mathrm{C}\right)$ にてかくはんしながら 24 時間反応させた。 反応終了後, 塩化メチレン/アセトン $(1 / 4)$ 混合溶媒から 結晶化することにより，目的とする錯体を得た。同様に して, NBDI-銅錯体および $\mathrm{H}_{6} \mathrm{XDI}$-銅錯体を合成した。

構造は元素分析およびIRにより推定した.

IPDI-Cu $(\mathrm{acac})_{2}$ : FT-IR $(\mathrm{KBr}) \boldsymbol{v}_{(\mathrm{CN})} 2361 \mathrm{~cm}^{-1}$, Anal. Calcd for $\mathrm{C}_{22} \mathrm{H}_{32} \mathrm{~N}_{2} \mathrm{CuO}_{6}: \mathrm{C}, 54.59 ; \mathrm{H}, 6.66 ; \mathrm{N}, 5.79 \%$. Found : C, $53.66 ; \mathrm{H}, 6.90 ; \mathrm{N}, 5.09 \%$.

NBDI-Cu $(\text { acac })_{2}$ : FT-IR $(\mathrm{KBr}) \boldsymbol{v}_{(\mathrm{CN})} 2363 \mathrm{~cm}^{-1}$, Anal. Calcd for $\mathrm{C}_{21} \mathrm{H}_{28} \mathrm{~N}_{2} \mathrm{CuO}_{6}: \mathrm{C}, 53.89 ; \mathrm{H}, 6.03 ; \mathrm{N}, 5.99 \%$. Found : C, $53.71 ; \mathrm{H}, 5.90 ; \mathrm{N}, 5.72 \%$.

$\mathrm{H}_{6} \mathrm{XDI}-\mathrm{Cu}(\mathrm{acac})_{2}:$ FT-IR $(\mathrm{KBr}) \boldsymbol{v}_{(\mathrm{CN})} 2361 \mathrm{~cm}^{-1}$, Anal. Calcd for $\mathrm{C}_{20} \mathrm{H}_{28} \mathrm{~N}_{2} \mathrm{CuO}_{6}: \mathrm{C}, 52.68 ; \mathrm{H}, 6.19 ; \mathrm{N}, 6.14 \%$. Found : C, $52.15 ; \mathrm{H}, 6.55 ; \mathrm{N}, 6.21 \%$.

\section{3 重合方法}

アルゴン雲囲気でシュレンク管に，それぞれあらかじ め調製した金属錯体 $(20.0 \mathrm{mg})$ と単量体である MMA $(4.26 \mathrm{~g}, 0.043 \mathrm{~mol})$ とを秤量する。金属錯体を入れた シュレンク管および単量体を入れたシュレンク管に THF（3.1 mL）をそれぞれ加え，金属錯体および単量体 を溶解させたのち, 凍結脱気を行う．単量体溶液をカ二 ユラーを用いて錯体を入れたシュレンク管に加えたの ち、アルゴン置換した $100 \mathrm{~mL}$ 重合瓶にカニュラーを用 いて移し, 反応温度 $50^{\circ} \mathrm{C}$ で最適時間（７2 時間）反応 させた。 反応終了後, 反応生成物を THFに溶解し, 大 量のメタノール中に投入することにより，生成ポリマー を沈殿させた，得られたポリマーは沪過し，沪過物（ポ リマー）は大量のメタノールで洗浄したのち, 減圧下に て乾燥させた。重合収率はポリマーの乾燥重量により求 めた。

\section{4 脂環式ジイソシアナートー銅錯体およびポリマー の分析}

NBDI-, $\mathrm{H}_{6} \mathrm{XDI}$-および IPDI-Cu (acac) ${ }_{2}$ 錯体の生成は元 素分析および IRにより確認した。IRの測定には日本分 光(株)製の FT/IR-5300を使用した。測定サンプルは KBr と細かく擦りまぜ高圧圧縮し, 直径約 $3 \mathrm{~mm}$, 厚さ約 0.1 $\sim 0.2 \mathrm{~mm}$ の小さな錠剤を成型し測定した $(\mathrm{KBr}$ 法). 元 素分析の測定は(株)武田分析研究所に依頼した。ポリマ 一の数平均分子量 $\left(M_{\mathrm{n}}\right)$ およびその分子量分布 $\left(M_{\mathrm{w}} / M_{\mathrm{n}}\right)$ はゲル浸透クロマトグラフィー（GPC）により，標準ポ リスチレンを使用して求めた，GPCには東ソー(株)製 GPC-8020 シリーズを用い, THFを溶出液として $40^{\circ} \mathrm{C}$ で測定した. 生成ポリマーの立体規則性は'H および ${ }^{13} \mathrm{C}$

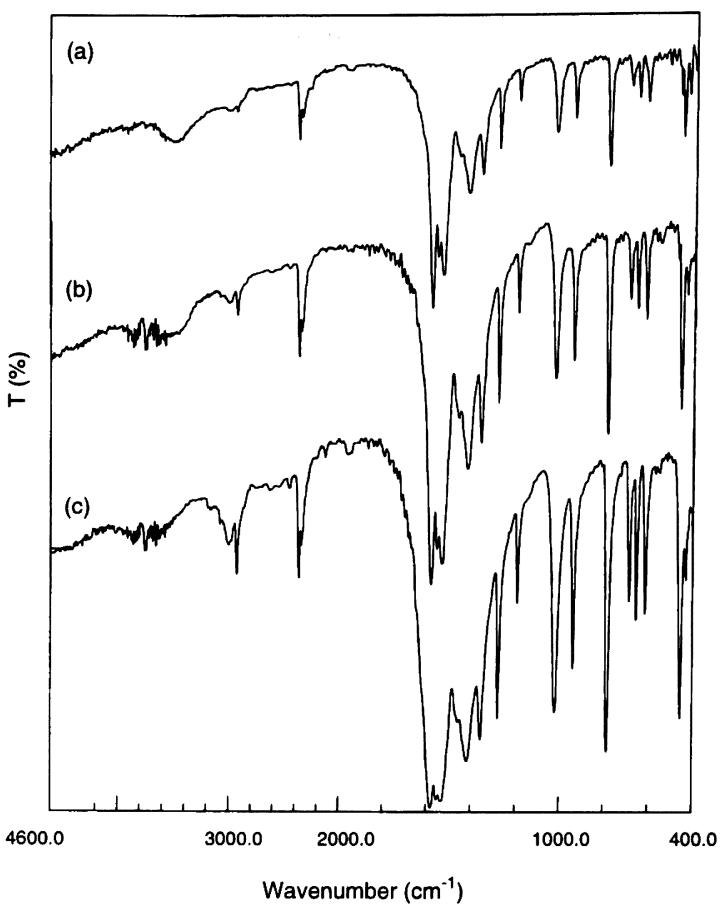

Fig. 1. IR spectra of diisocyanate- $\mathrm{Cu}(\mathrm{acac})_{2}$ complexes: (a) NBDI-Cu complex; (b) $\mathrm{H}_{6} \mathrm{XDI}-\mathrm{Cu}$ complex; (c) IPDI-Cu complex.

NMR スペクトルより求めた. NMRの測定には varian VNMR UNITY plus 300 を用い, 重クロロホルムを溶媒 とし,テトラメチルシラン（TMS）を内部標準として 測定を行った。

\section{3 結果と考察}

\section{1 脂環式ジイソシアナート-銅錯体の合成}

NBDI， $\mathrm{H}_{6} \mathrm{XDI}$ および IPDI と $\mathrm{Cu}(\mathrm{acac})_{2}$ 錯体とを塩化 メチレン中で, 室温にて 24 時間反応させ, 塩化メチレ ン/アセトン（1/4）混合溶媒で結晶化することにより， それぞれの錯体を得た. 元素分析の結果より, ジイソシ アナートと $\mathrm{Cu}(\mathrm{acac})_{2}$ との組成比がジイソシアナート/ $\mathrm{Cu}(\mathrm{acac})_{2}=1 / 1$ であることから，合成した種々のジイソ シアナートー銅錯体は 1 つの $\mathrm{Cu}(\mathrm{acac})_{2}$ に対してジイソ シアナートが1 1 分子配位していると推定できる. ジイソ シアナートー銅錯体のIR スペクトルを Fig. 1 に示す.そ れぞれのジイソシアナート配位子におけるイソシアナー 卜基（NCO）の $v_{(\mathrm{cN})}$ は 2256 2262 $\mathrm{cm}^{-1}$ に現れるが, 錯体形成により $\boldsymbol{V}_{(\mathrm{CN})}$ が約 $98 \sim 106 \mathrm{~cm}^{-1}$ 高波数側にシフ トした，それぞれの錯体の NCO 基のシフト值を Table 1 に示す．IRの遷移シフトによりその構造解析がすでに

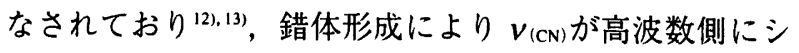
フトしていることから，イソシアナート配位子は NCO 基の窒素の孤立電子対で金属に配位していると考えられ 
Table 1. Chemical shift between diisocyanate and complex

\begin{tabular}{cc}
\hline \hline Complex & IR shift $\Delta v_{(\mathrm{CN})} \mathrm{cm}^{-1}$ \\
\hline $\mathrm{NBDI}-\mathrm{Cu}(\mathrm{acac})_{2}$ & 106.09 \\
$\mathrm{H}_{6} \mathrm{XDI}-\mathrm{Cu}(\mathrm{acac})_{2}$ & 98.38 \\
$\mathrm{IPDI}_{2} \mathrm{Cu}(\mathrm{acac})_{2}$ & 102.23 \\
\hline
\end{tabular}<smiles>O=NCC1C2CC(C[N+](=O)[O-])C1C2</smiles><smiles>O=NCC1CCCC(C[N+](=O)[O-])C1</smiles><smiles>CC1(C)CC([N+](=O)[O-])CC(C)(CN=O)C1</smiles>

NBDI

IPDI

Scheme 1.

る. ジイソシアナートの配位様式はその構造 (Scheme 1) から， 2 種類に分けられる. ジイソシアナートの NCO 基の片方だけが隣接するメチレン基をもつものと, NCO 基の両方に隣接するメチレン基をもつものの 2 種類であ り, 前者の例が IPDI で, 後者の例が NBDI および $\mathrm{H}_{6}$ XDI である.すなわち, 錯体形成時における配位形態は NBDI と $\mathrm{H}_{6} \mathrm{XDI}$ とは同じであるのに対し，IPDI はNBDI およ び $\mathrm{H}_{6} \mathrm{XDI}$ とは異なっていることを示唆するものである. これは, 後述する MMA の重合速度式が NBDI-および $\mathrm{H}_{6}$ $\mathrm{XDI}-\mathrm{Cu}(\mathrm{acac})_{2}$ 錯体はほほ同じで, IPDI-Cu $(\mathrm{acac})_{2}$ 錯体 は大きく異なることからも支持される，単結晶の単離が できず，X 線結晶解析ができない現状では，錯体の明確 な構造決定は不可能であるが, IPDIは隣接するメチレ ン基をもつ NCO 基 1 つで錯体形成するのに対し，NBDI および $\mathrm{H}_{6} \mathrm{XDI}$ は 2 つの NCO 基でより安定な錯体を形成 していることが推定できる。

\section{2 脂環式ジイソシアナートー銅錯体を触媒に用いた 重合反店}

3.2.1 脂環式ジイソシアナート一銅錯体を用いたメタ クリル酸メチルの重合 NBDI-, $\mathrm{H}_{6}$ XDI-および IPDI-Cu $(\mathrm{acac})_{2}$ 錯体を用いて MMAの重合反応を $50^{\circ} \mathrm{C} に て 72$ 時間行い，その結果を Table 2 に示す。それぞれの錯体 において重合は進行し; 収率は $80 \%$ 以上であった。 ま た, MMAの熱重合での $M_{\mathrm{w}} / M_{\mathrm{n}}$ が 3.51 と幅広いのに対 し, 触媒を用いた重合反応では, $M_{\mathrm{w}} / M_{\mathrm{n}}$ は $1.26 \sim 1.37$ と非常に狭く， $M_{\mathrm{n}}$ も 70 万以上と高分子量のポリマーが 得られ，脂環式ジイソシアナート一銅錯体には優れた触 媒作用があることが明らかとなった．とりわけ，IPDI-Cu (acac) $)_{2}$ 錯体を用いた場合の $M_{w} / M_{\mathrm{n}}$ がもっとも狭く 1.26 であり， $M_{\mathrm{n}}$ は $97.1 \times 10^{4}$ であった。 ジイソシアナートー 銅錯体は, ラジカル重合開始剤であるアゾビスイソブチ ロニトリル (AIBN) と比較して, 重合速度 $\left(R_{\mathrm{p}}\right)$ が小 さく，特に IPDI-Cu(acac $)_{2}$ 錯体による MMA の $R_{\mathrm{p}}$ は，

Table 2. Polymerization of MMA with diisocyanate-Cu(acac) catalyst in $\mathrm{THF}^{\mathrm{a}}$

\begin{tabular}{cccc}
\hline \hline Ligand & Yield(\%) & $M_{\mathrm{n}}\left(\times 10^{4}\right)$ & $M_{\mathrm{w}} / M_{\mathrm{n}}$ \\
\hline none & 77.1 & 16.4 & 3.51 \\
NBDI & 95.0 & 72.6 & 1.29 \\
H6XDI & 93.2 & 73.6 & 1.37 \\
IPDI & 82.9 & 97.1 & 1.26 \\
\hline
\end{tabular}

a) $\left[\right.$ catalyst $=4.76 \times 10^{-3} \mathrm{~mol} / \mathrm{L}$; $[\mathrm{MMA}]=5.31 \mathrm{~mol} / \mathrm{L}$; Temp.= $50^{\circ} \mathrm{C}$; Time $=72 \mathrm{~h}$.

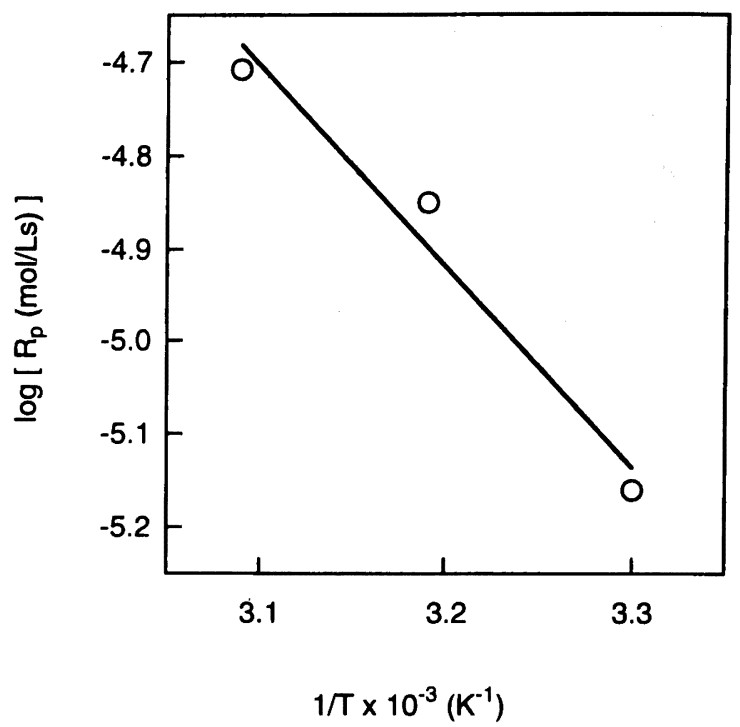

Fig. 2. Arrhenius plots for the polymerization of MMA with IPDI-Cu(acac $)_{2}$ catalyst in THF: [IPDI-Cu(acac $)_{2}$ ] $=5.30$ $\times 10^{-3} \mathrm{~mol} / \mathrm{L} ;[\mathrm{MMA}]=5.32 \mathrm{~mol} / \mathrm{L}$.

ほかのジイソシアナート-銅錯体に比べて小さい。一般 に $R_{\mathrm{p}}$ と $M_{\mathrm{n}}$ との関係は， $R_{\mathrm{p}}$ が大きいほど $M_{\mathrm{n}}$ が低下する ことが知られており (4), AIBN と比較して, $R_{\mathrm{p}}$ が小さく なる原因としては, ジイソシアナート一銅錯体が成長ラ ジカルを安定化させることによるものと考えられ，成長 ラジカルの安定化が高分子量化 $\left(M_{\mathrm{n}}>90 \times 10^{4}\right)$ を可能 にすると考えられる。

もっとも, 触媒活性の高い IPDI-Cu (acac) 2 錯体を用い て, MMAの重合における温度の影響を検討したところ， 重合温度の上昇に伴い, 重合速度が速くなることが認め られた。この結果をもとにアレニウスプロットを行った ところ， $R_{\mathrm{p}}$ と重合温度との関係は Fig. 2 に示すような 直線関係であることが明らかとなった。この直線の傾き から求めた全重合の活性化エネルギーは $42.5 \mathrm{~kJ} / \mathrm{mol}$ で あった。また，NBDI-扩よび $\mathrm{H}_{6} \mathrm{XDI}-\mathrm{Cu}(\mathrm{acac})_{2}$ 錯体を用 いた重合反応においても同様にして全重合の活性化エネ ルギーを求めたところ, $47.3 \mathrm{~kJ} / \mathrm{mol}$ および $48.6 \mathrm{~kJ} / \mathrm{mol}$ であった．無触媒および触媒先駆体である $\mathrm{Cu}(\mathrm{acac})_{2}$ の 


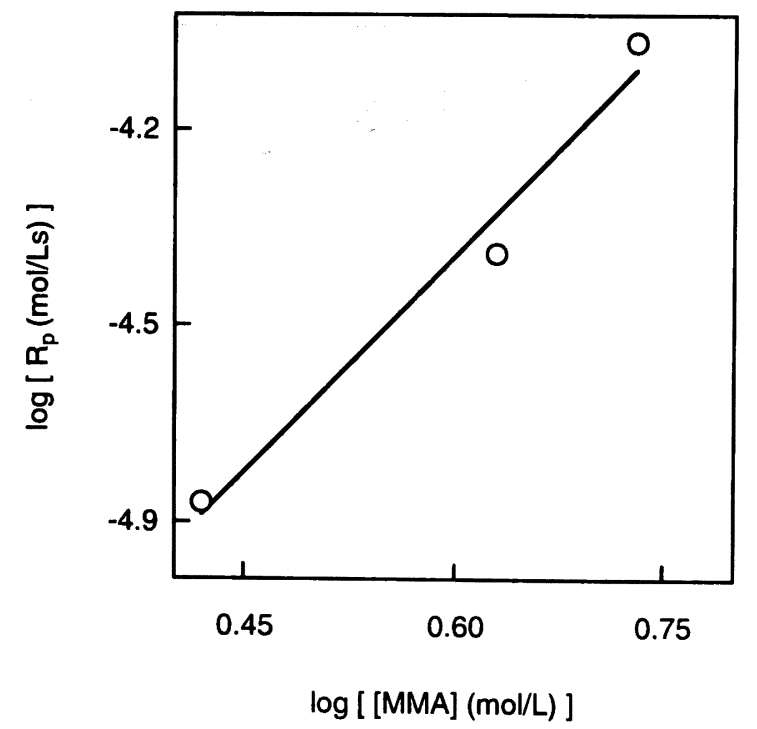

Fig. 3. Dependence of $R_{\mathrm{p}}$ on monomer concentration for the polymerization of MMA with IPDI-Cu(acac $)_{2}$ catalyst in THF at $50^{\circ} \mathrm{C}$ for $24 \mathrm{~h}$ : [cat] $=1.52 \times 10^{-2} \mathrm{~mol} / \mathrm{L}$.

活性化エネルギー（142.7 kJ/mol および $168.4 \mathrm{~kJ} / \mathrm{mol} ）$ よ りはるかに低い值を示す。これはジイソシアナートー銅 錯体を用いることで, 比較的温和な条件下で重合が進行 することを示唆するものである.

$\mathrm{IPDI}-\mathrm{Cu}(\mathrm{acac})_{2}$ 錯体による $\mathrm{MMA} の R_{\mathrm{p}} に$ 及ほす単量 体濃度の影響について検討し，その結果を Fig. 3 に示す. 単量体濃度と $R_{\mathrm{p}}$ との間には直線関係が得られた。この 直線の傾きから IPDI-Cu $(\mathrm{acac})_{2}$ 錯体の $R_{\mathrm{p}}$ は単量体濃度 の 2.3 乗に比例することが明らかとなった。触媒濃度の 効果についても検討し，その結果を Fig. 4 に示す. $R_{\mathrm{p}}$ と触媒濃度との間には直線関係が成立し，その傾きから 触媒濃度の $R_{\mathrm{p}}$ への依存性は 0.44 次と求まった。また, NBDI-および $\mathrm{H}_{6} \mathrm{XDI}-\mathrm{Cu}(\mathrm{acac})_{2}$ 錯体による MMA の $R_{\mathrm{p}}$ に 及ほす単量体濃度打よび触媒濃度の影響についても同様 に検討を行い， $R_{\mathrm{p}}$ と単量体濃度および $R_{\mathrm{p}}$ と触媒濃度と の間には直線関係が成立した。これらの結果から、ジイ ソシアナートー銅錯体による MMAの重合速度式はそれ ぞれ次式で示される.

$$
\begin{aligned}
& R_{\mathrm{p}}=k[\mathrm{MMA}]^{2.3}\left[\mathrm{IPDI}-\mathrm{Cu}(\mathrm{acac})_{2}\right]^{0.44} \\
& R_{\mathrm{p}}=k[\mathrm{MMA}]^{1.2}\left[\mathrm{NBDI}-\mathrm{Cu}(\mathrm{acac})_{2}\right]^{0.68} \\
& R_{\mathrm{p}}=k[\mathrm{MMA}]^{1.0}\left[\mathrm{H}_{6} \mathrm{XDI}-\mathrm{Cu}(\mathrm{acac})_{2}\right]^{0.57}
\end{aligned}
$$

ジイソシアナートー銅錯体の重合速度式から, 重合の 機構は大きく 2 種類に分類される. $R_{\mathrm{p}}$ の単量体濃度の 依存性から, IPDI-Cu (acac) 2 錯体は単量体との錯体形成 が示唆され(14)-16), NBDI-および $\mathrm{H}_{6} \mathrm{XDI}-\mathrm{Cu}(\mathrm{acac})_{2}$ 錯体で はフリーラジカルによる重合の開始が示唆されるい7.こ れは, ジイソシアナートー銅錯体の構造に大きく起因す ると考えられる，前述したように，IPDIは隣接するメ

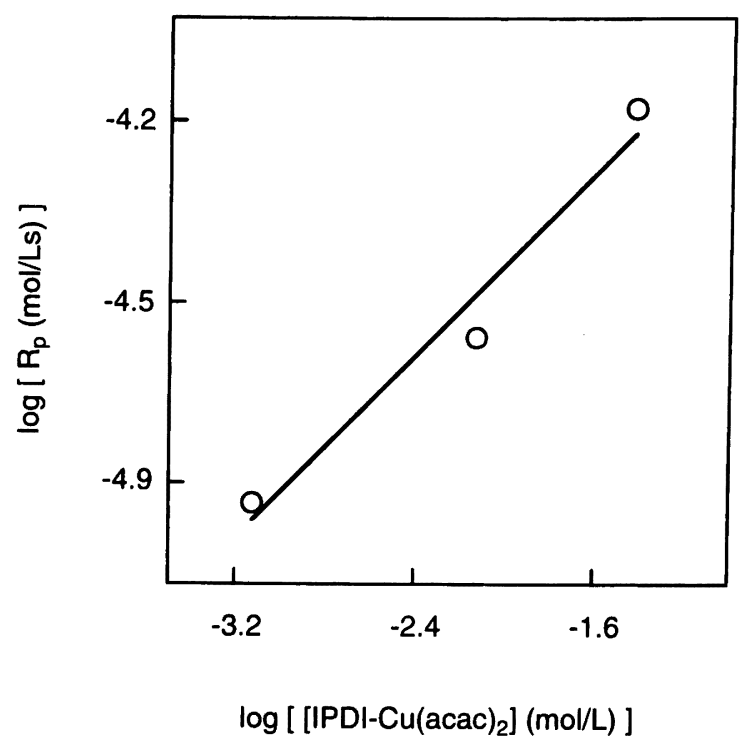

Fig. 4. Dependence of $R_{\mathrm{p}}$ on catalyst concentration for the polymerization of MMA with IPDI-Cu(acac) $)_{2}$ catalyst in $\mathrm{THF}$ at $50^{\circ} \mathrm{C}$ for $24 \mathrm{~h}:$ [MMA] $=5.32 \mathrm{~mol} / \mathrm{L}$.

チレン基をもつ 1 つの NCO 基で金属に配位しているこ


子自体にフレキシビリティーがあり，そのために基質 （MMA）の接近を妨害あるいは抑制することなく触媒と して機能すると考えられ，重合の開始は単量体との錯体 形成を伴う中間体を経由することが示唆される。一方, $\mathrm{NBDI}$-および $\mathrm{H}_{6} \mathrm{XDI}-\mathrm{Cu}(\mathrm{acac})_{2}$ 錯体は，2つの NCO 基と 安定な錯体形成をするために, 単量体との錯体形成をす ることが困難であると考えられる，以上のことは，重合 速度式における， $R_{\mathrm{p}}$ の単量体濃度の依存性に大きく反 映されている。NBDI-および $\mathrm{H}_{6} \mathrm{XDI}-\mathrm{Cu}(\mathrm{acac})_{2}$ 錯体では その重合の開始はフリーラジカルであり, 重合の開始反 応において直接的な関与はないが，これら2つの錯体か ら得られるポリマーの $M_{\mathrm{w}} / M_{\mathrm{n}}$ は前述したように, 1.29 および 1.37 と狭いことあるいは $M_{\mathrm{n}}$ が 70 万以上である ことを考慮すると，錯体による反応の制御の可能性が十 分に考えられる(7). 重合の開始反応には関与しなくとも, 重合が進行すると NBDI-および $\mathrm{H}_{6} \mathrm{XDI}-\mathrm{Cu}(\mathrm{acac})_{2}$ 錯体が 関与している可能性を否定できない.

3.2.2 脂環式ジイソシアナートー銅錯体により得られ る生成ポリマーの立体規則性 生成ポリマー(ポリメ夕 クリル酸メチル：PMMA）の立体規則性に及ほす IPDI$\mathrm{Cu}(\mathrm{acac})_{2}$ 錯体の影響を検討した. 得られた PMMAの立 体規則性を Table 3 に示す. IPDI-Cu (acac) 2 錯体を用い た MMA の重合で得られるPMMAの立体規則性はシン ジオタクト $(r r)$ 連鎖に富み, 反応がラジカル的に進行 していることを示唆している.ラジカル重合でのポリマ 一の立体制御は, おもに成長ラジカル末端と単量体の立 
Table 3. Tacticity of the PMMA for each catalytic concentration

\begin{tabular}{cccc}
\hline \hline [Catalyst] $^{\text {a) }}$ & \multicolumn{3}{c}{ Tacticity of PMMA } \\
\cline { 2 - 4 } $\mathrm{mol} / \mathrm{L}$ & $\mathrm{mm}$ & $\mathrm{mr}$ & $\mathrm{rr}$ \\
\hline $7.52 \times 10^{-4}$ & 02.2 & 29.3 & 68.5 \\
$7.52 \times 10^{-3}$ & 02.7 & 29.4 & 67.9 \\
$3.76 \times 10^{-2}$ & 15.1 & 25.9 & 59.0 \\
\hline
\end{tabular}

a) IPDI-Cu(acac $)_{2}$ complex.

体的な要因とに依存し，通常 PMMA は $r r$ 連鎖に富むも のである. 触媒濃度が低い場合, 生成する PMMA の立 体規則性に対して, 触媒の影響はほとんどないが, 触媒 濃度が高くなるに従い,アイソタクト $(\mathrm{mm})$ 連鎖が約 $13 \%$ 増加し, 通常のラジカル重合で得られるポリマー に比べて $\mathrm{mm}$ 連鎖に富むものが得られた。 反応の初期 の段階において，IPDI-Cu ( acac) 2 錯体の影響すなわち錯 体への基質の配位による立体規則性の制御が考えられ, さらに徐々に重合が進行していくと，ポリマー成長末端 はその前の数単量体単位の置換基間の相互作用により大 きな累積効果を受け, PMMA は比較的 $\mathrm{mm}$ 連鎖に富む ものが得られると考えられる。しかし，その影響はそれ ほど強いものではないため, IPDI-Cu ( acac) 2 錯体の触媒 濃度に依存すると考えられる。

一方, NBDI-および $\mathrm{H}_{6} \mathrm{XDI}-\mathrm{Cu}$ (acac) ${ }_{2}$ 錯体については 触媒濃度の変化にかかわらず, 得られる PMMAの立体 規則性は変化せず, $r r$ 連鎖に富むものである（NBDI-Cu $(\mathrm{acac})_{2}: \mathrm{mm} / \mathrm{mr} / \mathrm{rr}=2.7 / 30.9 / 66.4, \mathrm{H}_{6} \mathrm{XDI}-\mathrm{Cu}(\mathrm{acac})_{2}$ : $\mathrm{mm} / \mathrm{mr} / \mathrm{rr}=3.2 / 33.3 / 63.5)$.

3.2.3 脂環式ジイソシアナートー銅錯体を用いた重合 におけるメタクリル酸エステルの置換基の影響 ジイソ シアナートー銅錯体を用いてメタクリル酸エステル (MMA, メタクリル酸エチル (EMA), メタクリル酸 $n-$ ブチル (BMA)) の重合反応を $50^{\circ} \mathrm{C} に 24$ 時間行い, その結果を Fig. 5 に示す. NBDI-および $\mathrm{H}_{6} \mathrm{XDI}-\mathrm{Cu}(\mathrm{acac})_{2}$ 錯体を触媒として用いた場合には， $R_{\mathrm{p}}$ はほほ同じ傾向 を示すが, IPDI-Cu( $\mathrm{acac})_{2}$ はエステルの置換基の炭素数 が増加するとまったく異なる $R_{\mathrm{p}}$ 示す． $R_{\mathrm{p}}$ はメタクリル 酸エステルの反応性（二重結合）およびその置換基の立 体的影響を受けるため, メタクリル酸エステルの置換基 の炭素数が MMA（C：1）, EMA（C：2）および BMA （C：4）と大きくなるに従い減少するが, ここでも錯体 の配位形態の差によって減少の度合いに影響が表れてい る.

\section{4 結 論}

脂環式ジイソシアナートー銅錯体を合成し，MMAの 重合を検討した。ジイソシアナートー銅錯体から得られ るポリマーは， $M_{\mathrm{n}}$ が 70 万以上と高分子量体であり，

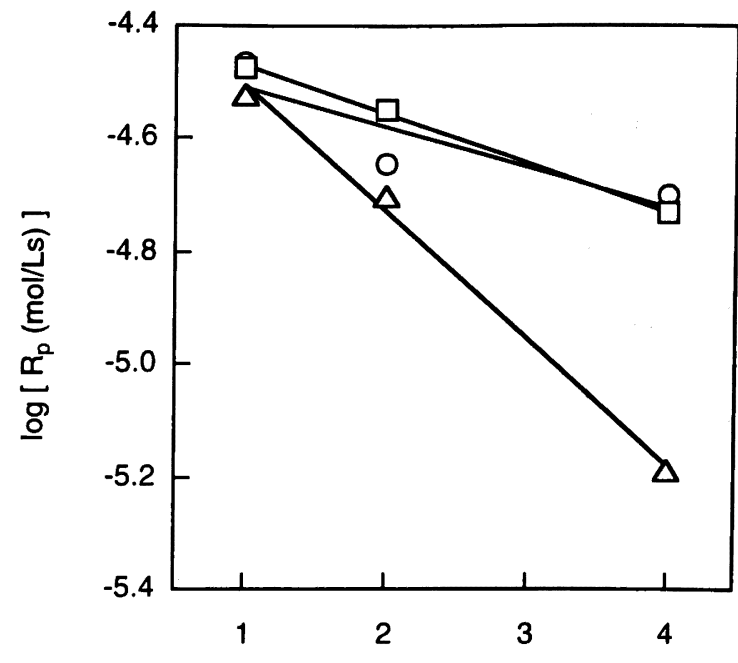

Carbon number

Fig. 5. Relationship between substituent carbon number of methacrylic ester with $R_{\mathrm{p}}$ on polymerization: $\bigcirc$, NBDI-Cu $(\text { acac })_{2} ; \square, \mathrm{H}_{6} \mathrm{XDI}-\mathrm{Cu}(\mathrm{acac})_{2} ; \triangle$, IPDI-Cu(acac $)_{2}$.

$M_{\mathrm{w}} / M_{\mathrm{n}}$ は 1.4 以下と非常に狭いものであった。ジイソシ アナートー銅錯体を触媒に用いた MMAの重合は，ジイ ソシアナートー銅錯体の立体的因子に大きく左右される ことが明らかとなった，とりわけ，IPDI-Cu(acac) 2 錯体 においては，得られる PMMA の立体規則性に影響を与 え，比較的アイソタクト連鎖に富むものが得られた。さ らに, メタクリル酸エステルの重合での, ジイソシアナ ート一銅錯体の立体効果を検討したところ，配位子の違 いにより反応性が異なり, 配位子の構造が重合に大きく 関与していることが明らかとなった.

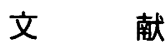

1) H. Frauenrath, H. Keul, and H. Hoecker, Macromolecules, 34, 14 (2001).

2) P. A. Cameron, V. C. Gibson, and A. J. Graham, Macromolecules, 33, 4329 (2000).

3) T. Stuhldreier, H. Keul, and H. Hoecker, Macromol. Rapid Commun., 21, 1093 (2000).

4) H. Nguyen, A. P. Jarvis, M. J. G. Lesley, Y. W. M. Kell, S. S. Reddy, N. J. Taylor, and S. Collins, Macromolecules, 33, 1508 (2000).

5) K. Endo and Y. Yamanaka, Polym. Int., 49, 110 (2000).

6) E. Ihara, T. Fujimura, H. Yasuda, T. Maruo, N. Kanehisa, and Y. Kai, J. Polym. Sci., Part A: Polym. Chem., 38, 4764 (2000).

7) K. Tsuchihara, Y. Suzuki, M. Asai, and K. Soga, Polym. J., 32, 700 (2000)

8) K. Endo, A. Inukai, and T. Otsu, Polym. Int., 35, 287 (1994)

9) K. Endo and A. Inukai, Polym. Int., 49, 110 (2000).

10) H. Yasuda, E. Ihara, T. Fujimura, Y. Maeno, K. Ogata, Y. Sato, and G. Desurmond, J. Synth. Org. Chem., 58, 1084 (2000).

11) 永井康晴, 井上県一, 岡本 弘, 高分子論文集, 58, 606 (2001). 
12) A. H. Norbury and A. I. P. Sinha, J. Chem. Soc. A, 1968, 1598

13) J. Nelson and S. M. Nelson, J. Chem. Soc. A, 1969, 1597.

14) 上原 赫, 松村武明, 村田祐一, 田中 誠, 村田二郎, 工業化学 雑誌, 72, 1825 (1969).
15) 上原 赫, 片岡仁孝, 亀井清弘, 田中 誠, 村田二郎, 工業化学 雑誌, 72, 1831 (1969).

16) 西川幸利, 大津隆行, 工業化学雑誌, 72, 1836 (1969)

17) 大津隆行, 西川幸利, 青木修三, 工業化学雑誌, 71, 1067 (1968).

Polymerization of Methyl Methacrylate with Alicyclic Diisocyanates-copper Acethylacetonate Complexes

Shin-ichi INOUE, ${ }^{* 1}$ Yuji MAEDA, ${ }^{* 1}$ Yasuharu NAGAI, ${ }^{* 1}$ and Hiroshi OKAMOTO ${ }^{* 1}$

*'Department of Applied Chemistry, Aichi Institute of Technology (Yachigusa, Yagusa-cho, Toyota, Aichi 470-0392, Japan)

The polymerization of methyl methacrylate (MMA) with diisocyanate-Cu(acac) $)_{2}$ complexes prepared from alicyclic diisocyanates, 2,5 (2,6)-bis(isocyanatomethyl)bicyclo[2.2.1] heptane (NBDI), 1,3-bis(isocyanatomethyl) cyclohexane ( $\mathrm{H}_{6} \mathrm{XDI}$ ), and 3-isocyanatomethyl-3,5,5trimethylcyclohexylisocyanate (IPDI), and copper acethylacetonate was investigated. When polymerizations catalyzed by diisocyanate-Cu $(\text { acac })_{2}$ complexes were carried out for $24 \mathrm{~h}$ at $60^{\circ} \mathrm{C}$ in THF, IPDI-Cu(acac) $)_{2}$ complex showed high activity and the narrow molecular distribution $\left(M_{\mathrm{w}} / M_{\mathrm{n}}=1.26\right)$, and the number average molecular weight $\left(M_{\mathrm{n}}\right)$ of the resulting polymer was 971000 . From a kinetic study using the copper complex, the polymerization rate $\left(R_{\mathrm{p}}\right)$ can be expressed as $R_{\mathrm{p}}=k[\mathrm{MMA}]^{2.3}\left[\mathrm{IPDI}-\mathrm{Cu}(\mathrm{acac})_{2}\right]^{0.44}$. The overall activation energy of the polymerization was determined to be $42.5 \mathrm{~kJ} / \mathrm{mol}$. In the case of IPDI-Cu(acac $)_{2}$ complex, the resulting polymers were somewhat rich in
isotactic structure. KEY WORDS Diisocyanate-metal Complexes / Alicyclic Diisocyanate / Isophorone Diisocyanate / Copper Acetylacetonate / Polymeriza-
tion / Methyl Methacrylate /

(Received November 8, 2001: Accepted January 28, 2002)

[Kobunshi Ronbunshu, 59(4), 212-217 (2002)] 